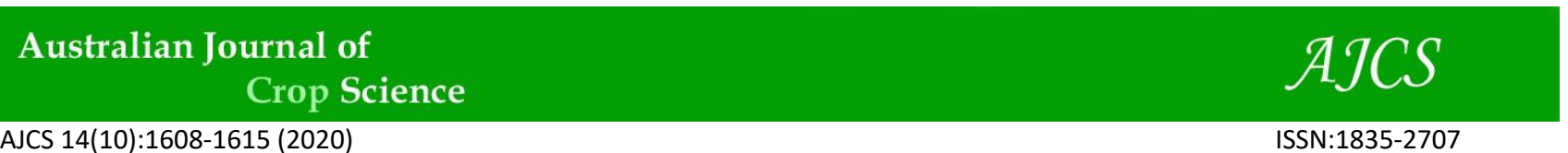

AJCS 14(10):1608-1615 (2020)

ISSN:1835-2707

doi: $10.21475 /$ ajcs.20.14.10.p2389

\title{
Tetradenia riparia (Lamiaceae) essential oil: an alternative to Rhipicephalus sanguineus
}

\author{
Giuliana Zardeto-Sabec ${ }^{1}$, Renan Almeida de Jesus ${ }^{1}$, Herika Line Marko de Oliveira ${ }^{1}$, Caio Franco de Araújo \\ Almeida Campo ${ }^{2}$, Ezilda jacomassi ${ }^{4}$, José Eduardo Gonçalves ${ }^{2,3}$ and Zilda Cristiani Gazim ${ }^{1^{*}}$ \\ ${ }^{1}$ Programa de Pós-Graduação em Biotecnologia Aplicada à Agricultura. Universidade Paranaense - UNIPAR, Praça \\ Mascarenhas de Moraes, 4282, CEP 87502-210, Umuarama-PR, Brasil \\ ${ }^{2}$ Mestrado em Tecnologia Limpas e ${ }^{3}$ Instituto Cesumar de Ciência, Tecnologia e Inovação - ICETI. Centro \\ Universitário Cesumar-UNICesumar, Av. Guedner, 1610. Jardim Aclimação, Maringá, Paraná, 87050-900, Brasil \\ ${ }^{4}$ Mestrado Profissional em Plantas Medicinais e Fitoterápicos na Atenção Básica, Universidade Paranaense \\ (UNIPAR), Praça Mascarenhas de Moraes, 4282, Umuarama, PR, 87502-210, Brasil
}

\section{*Corresponding author: cristianigazim@prof.unipar.br}

\begin{abstract}
In Brazil, Rhipicephalus sanguineus resistance to some pyrethroids have been detected, motivating research on new phytoinsecticides such as essential oil from Tetradenia riparia leaves $\left(\mathrm{EO}_{\mathrm{L}}\right)$ and flower buds $\left(\mathrm{EO}_{\mathrm{FB}}\right)$. The essential oils were obtained by hydrodistillation ( $3 \mathrm{~h}$ ) and identified by GC/MS. In addition, a multivariate exploratory analysis was done to determine the analysis of the major compounds (PCA). The bioassays on $R$. sanguineus larvae were done by immersion test at different EO concentrations which ranged from 50,000 to $0.47 \mathrm{mg} / \mathrm{mL}(\mathrm{v} / \mathrm{v})$. The action mechanism of EOs were determined by bioautographic method evaluating the inhibitory potential on the acetylcholinesterase enzyme. The EO yield in leaves was $0.29 \pm 0.22$ (\%) and in flower buds $0.38 \pm 0.17$ (\%). The class projections showed oxygenated sesquiterpenes (43.62\%) and diterpenes (15.60\%) in $\mathrm{EO}_{\mathrm{FB}}$, and hydrocarbon sesquiterpenes $(26.44 \%)$ and oxygenated monoterpenes $(16.44 \%)$ in $\mathrm{EO}_{\mathrm{L}}$. Four components presented a greater distancing of mass flow: fenchone (11.57 and $6.01 \%), \alpha$-cadinol (12.21 and $13.69 \%), 14$-hidroxy-9-epi-caryophyllene (8.56 and $15.38 \%)$, and caryophyllene oxide (1.32 and $4.50 \%)$ in $\mathrm{EO}_{\mathrm{L}}$ and $\mathrm{EO}_{\mathrm{FB}}$, respectively. The lethal concentrations (LCs) to kill $R$. sanguineus larvae were ( $\mathrm{LC}_{50}: 2.18 \pm 0.24$ and $\mathrm{LC}_{99.9}: 9.98 \pm 0.10 \mathrm{mg} / \mathrm{mL}$ ) for $\mathrm{EO}_{\mathrm{L}}$, and $\left(\mathrm{LC}_{50}: 5.36 \pm 2.50\right.$ and $\left.\mathrm{LC}_{99.9}: 20.12 \pm 0.54 \mathrm{mg} / \mathrm{mL}\right)$ for $\mathrm{EO}_{\mathrm{FB}}$. The action mechanism of EOs by bioautographic methods indicated an inhibition of $0.70 \mathrm{mg} / \mathrm{mL}\left(\mathrm{EO}_{\mathrm{L}}\right) \mathrm{and} 1.40 \mathrm{mg} / \mathrm{mL}$ $\left(\mathrm{EO}_{\mathrm{FB}}\right)$ on the acetylcholinesterase enzyme (AChE). Therefore, this species can be considered promising to be part of the chemical larvicides to control this ectoparasite.
\end{abstract}

Keywords: dog ticks, monoterpenes, fenchone, limonene, camphor, acetylcholinesterase, bio insecticides, falsa mirra. Abbreviations: GC/MS_gas chromatographer coupled to mass spectrometer; LC_lethal concentration; LC99.9_lethal concentration to eliminate $99.9 \%$ of larvae and ticks, LC50_lethal concentration to eliminate $50 \%$ of larvae and ticks.

Introduction

Rhipicephalus sanguineus, a cosmopolitan tick is probably the most distributed ixodid worldwide (Szabó et al., 2009), and has been found more and more often in man's home and peridomicilliary environments of the main urban host of this ectoparasite, the domestic dog Canis familiaris (Paz et al., 2008). In dogs, besides the direct damages, this ectoparasite is responsible for the transmission of Ehrlichia canis, Babesia canis, Haemobartonella canis and Hepatozoon canis. In humans, it is the vector of Rickettsia conorii and Rickettsia rickettsia, and this diagnosis is especially important once there have been reports on human parasitism by tick in Brazil (Borges et al., 2007). The growing number of cases of human parasitism by $R$. sanguineus has indicated that the interaction between human beings and $R$. sanguineus may be more common than it has been imagined (Cunha et al., 2009; Salkeld et al., 2019).

The control of this mite happens with the utilization of chemical acaricides from the classes of Isoxazolines (Afoxolaner, Fluralaner, Sarolaner and Lotilaner), Phenylpyrazoles (Fipronyl), Spinozins (Spinosad), Neonicotinoids (Nitempiram), Carbamates and Organophosphates (Pereira et al., 2008; Raimundo et al., 2017); however, the indiscriminate use of these substances resulted in the selection of resistant populations (Jeyathilakan et al., 2019). In Brazil, $R$. sanguineus resistance to some pyrethroids were recorded by Fernandes (2001), and since then the literature has been reporting that several synthetic acaricides have lost or reduced their efficiency due to the development of resistant strains (Brito et al., 2011). Another problem regards the number of animal and human 
poisonings mostly by organophosphates and carbamates (Raimundo et al., 2017; Bortolucci et al., 2018) due to the easy product acquisition and their indiscriminate utilization (Xavier et al., 2007).

Therefore, alternative controls have been studied and, therefore, the exploration of plants as efficient sources of botanical acaricides is promising and must be motivated (Sugauara et al., 2019). The utilization of secondary phytochemical metabolites have been able to interfere in arthropods' physiology such as neuroendocrine systems, feeding, metamorphoses, vulnerable points to population control based on arthropods' life cycle (Garcia and Azambuja, 2004).

Interest in the development of pesticide products with essential oils is based on studies that showed that they have repellent, fumigating, larvicidal and adulticide action (Tripathi and Mishra, 2016). The insecticide effect of essential oils occurs due to the variability of phytochemical standards and the way this phytomolecules penetrate the organism considering that essential oils can be inhaled, ingested or absorbed by the skin of insects (Magalhães et al., 2015). Another advantage to the use of essential oils regards their fast degradation in the environment and their increased specificity that favors benefic insects (Tripathi et al., 2009). Little is known on the physiological actions of essential oils on insects, but Kostyukovsky et al. (2002) suggested a neurotoxic action as it was shown with linalool that acts on the nervous system, affecting the ionic transport and the release of acetylcholinesterase in insects (Junior, 2003). This action mechanism was demonstrated in our study where $T$. riparia essential oil acted out by inhibiting acetylcholinesterase enzyme.

Tetradenia riparia (Hochst) Codd, from the Lamiaceae family (Souza and Lorenzi, 2005; Martins et al., 2008), is a plant utilized in popular medicine, and the essential oil extracted from its leaves has been used to treat malaria, criptococosis, candidiasis and respiratory infections (Van Puyvelde et al., 1986; Campbell et al., 1997; Okem et al., 2012, York et al., 2012). Studies carried out with this species have shown antimicrobial activity (Boily and Van Puyvelde 1986; Van Puyvelde et al. 1994; Gazim et al., 2010; Ndamane et al., 2013; Njau et al., 2014; Melo et al., 2015), repellent activity against Anopheles gambiae (Omolo et al., 2004), acaricidal and larvicidal (Gazim et al., 2011) and antileishmanial activities (Cardoso et al., 2015, Demarchi et al., 2015). Thus, this study aimed to investigate the larvicidal potential of essential oil from $T$. riparia leaves and flower buds against Rhipicephalus sanguineus tick.

\section{Results}

\section{Physical Aspects and Yield (\%)}

The essential oil from $T$. riparia leaves $\left(E_{\mathrm{L}}\right)$ presented orange color, yield of $0.29 \pm 0.22(\%)$, whereas the essential oil from flower buds $\left(\mathrm{EO}_{\mathrm{FB}}\right)$ had reddish orange color with yield of $0.38 \pm 0.17(\%)$.

Chemical Composition and Principal Components analysis (PCA)

Through the chemical analysis by GC/MS 48 compounds were identified in $\mathrm{EO}_{\mathrm{L}}$ and 56 in $\mathrm{EO}_{\mathrm{FB}}$ (Table 1). The class projection showed oxygenated sesquiterpenes (43.62\%) and oxygenated diterpenes $(15.60 \%)$ in $\mathrm{EO}_{\mathrm{FB}}$; and hydrocarbon sesquiterpenes $(26.44 \%)$ and oxygenated monoterpenes $(16.44 \%)$ in $\mathrm{EO}_{\mathrm{L}}$ ) (Fig 1).

Grouping by ACP was done including the major compounds identified in EO from leaves and flower buds. Four compounds out of them presented greater distancing of mass flow: L-fenchone (11.57 \% and $6.01 \%), \alpha$-cadinol (1.21 $\%$ and $13.69 \%$ ), 14-hidroxy-9-epi-caryophyllene (8.56 \% and $15.38 \%)$ and caryophyllene oxide (1.32\% and $4.50 \%)$, respectively (Fig 2 ).

\section{Larvicidal activity by Larval Packet Test}

The results found for larvicidal activity of $T$. riparia $\mathrm{EO}_{\mathrm{L}}$ and $\mathrm{EO}_{\mathrm{FB}}$ on Rhipicephalus sanguineus ae shown in Table 2 . The lethal concentrations (CLs) found to kill Rhipicephalus sanguineus larvae are presented in Table 3. Another important aspect within this study was to determine which action mechanism of the EO acted on $R$. sanguineus larvae. The Utilized protocol was based on the evaluation of the inhibitory capacity of EOS on the acetylcholinesterase enzyme by bioautographic method and whose results are shown on Table 4. The leaves essential oil presented greater larvicidal activity ( $\mathrm{CL}_{99.9} 9.98 \mathrm{mg} / \mathrm{mL}$ ) when compared to the essential oil from flower buds ( $\mathrm{CL}_{99.9} 20.12 \mathrm{mg} / \mathrm{mL}$ ). This difference can be related to the greater amount of hydrocarbon and oxygenated monoterpenes in $\mathrm{EO}_{\mathrm{L}}$ (23.21\%) when compare to $\mathrm{EO}_{\mathrm{FB}}(10.80 \%)$ according to Table 1 and Figures 1 and 2, because, according to Tripathi and Mishra (2016), monoterpenes present insecticide potential and, according to Lee et al. (2004), this potential can be explained by the fact that the compounds are volatile, lipophilic and able to quickly penetrate inside insects interfering in their physiological functions. Analyzing the chemical composition of $T$. riparia essential oil, four monoterpenes are found in greater amount in $\mathrm{EO}_{\mathrm{L}}$ when compared to $\mathrm{EO}_{\mathrm{FB}}$ : L-fenchone (11.57; 6.01\%), limonene (1.16; 0.37\%), L-camphor (2.38; $1.36 \%), \alpha$-pinene $(1.57 ; 0.23 \%)$ and 8 -caryophyllene $(5.70$; $3.85 \%)$, respectively, which present potential insecticide by bibliographic review as described in Table 5. Limonene has pytoinsecticide potential and is an active ingredient in commercially available shampoo against fleas (Athea Laboratories, Inc., Cornell, USA) (Tripathi et al., 2009). Also, it can be used in combination with detergent to control aphids, mealybugs, ants, fleas, ticks and mites (Moreira et al., 2006). The utilization of this compound is safe due to its low lethal concentration $\left(\mathrm{LC}_{50}\right)$ which is higher than 5.000 $\mathrm{mg} / \mathrm{kg}$. The bio insecticide potential of L-fenchone was studied by Sánchez-Ramos and Castañaera (2001) in female Tyrophagus putrescentiae (Schrank) mites exposed to inhalation $(9.0 \mu \mathrm{l} / \mathrm{L})$ of fenchone for $24 \mathrm{~h}$, resulting in $100 \%$ of mortality. The larvicidal activity of monoterpenes $\alpha$ and 8 -pinene on $R$. (B.) microplus tick was measured by Prates et al. (1993) and the results indicated $100 \%$ lethality of larvae in 10 minutes of exposure. Sutherst et al. (1982) attributed the toxic effect that caused the immobilization and death of $100 \%$ of $R$. (B.) microplus larvae to a mixture of $\alpha$-pinene and 6 -pinene, found in tropical legumes Stylosanthes scabra and S. viscosa, after 24 hours of contact with these legumes. In research studies developed by Prates et al. (1998), it took (+)-camphor 60 minutes to 
Table 1. Chemical composition of essential oil from Tetradenia riparia leaves and flower buds.

\begin{tabular}{|c|c|c|c|c|c|}
\hline \multirow[b]{2}{*}{ Peak } & \multirow[b]{2}{*}{${ }^{\mathrm{a}}$ Compounds } & \multicolumn{4}{|c|}{ Relative Area (\%) } \\
\hline & & Leaves & Flower buds & ${ }^{\mathrm{b}} \mathrm{RI}$ & Identification methods \\
\hline 1 & $\alpha$-pinene & 1.57 & 0.23 & 901 & $a, b, c$ \\
\hline 2 & Camphene & 1.22 & 0.16 & 913 & $a, b, c$ \\
\hline 3 & Sabinene & 1.41 & 0.34 & 930 & $a, b, c$ \\
\hline 4 & 8-pinene & 0.73 & 0.23 & 935 & $a, b, c$ \\
\hline 5 & Limonene & 1.16 & 0.37 & 973 & $a, b, c$ \\
\hline 6 & Cis-ocimene & 0.49 & 0.09 & 976 & $a, b, c$ \\
\hline 7 & Trans- 6 -ocimene & - & 0.30 & 977 & $a, b, c$ \\
\hline 8 & $\delta$ - terpinene & 0.20 & - & 996 & $a, b, c$ \\
\hline 9 & L-fenchone & 11.57 & 6.01 & 1111 & $a, b, c$ \\
\hline 10 & Fenchol & 0.81 & 0.55 & 1122 & $a, b, c$ \\
\hline 11 & L-camphor & 2.38 & 1.36 & 1136 & $a, b, c$ \\
\hline 12 & Borneol L & 0.82 & 0.61 & 1145 & $a, b, c$ \\
\hline 13 & Terpinene-4-ol & 0.46 & 0.16 & 1150 & $a, b, c$ \\
\hline 14 & L- $\alpha$-Terpineol & 0.40 & 0.39 & 1155 & $a, b, c$ \\
\hline 15 & Bicycloelemene & 0.34 & 0.31 & 1314 & $a, b, c$ \\
\hline 16 & $\alpha$-copaene & 0.88 & 0.47 & 1334 & $a, b, c$ \\
\hline 17 & B-elemene & 0.68 & 0.53 & 1342 & $a, b, c$ \\
\hline 18 & $\alpha$-gurjunene & 1.69 & 1.33 & 1350 & $a, b, c$ \\
\hline 19 & B-caryophyllene & 5.70 & 3.85 & 1354 & $a, b, c$ \\
\hline 20 & Trans- $\alpha$-bergamotene & 0.83 & 0.69 & 1461 & $a, b, c$ \\
\hline 21 & Aromadendrene & 0.36 & - & 1468 & $a, b, c$ \\
\hline 22 & $\alpha$-humulene & 0.59 & 0.24 & 1468 & $a, b, c$ \\
\hline 23 & Trans-6-farnesene & 0.31 & 0.23 & 1471 & $a, b, c$ \\
\hline 24 & Allo- aromadendrene & 0.30 & 0.42 & 1478 & $a, b, c$ \\
\hline 25 & $\alpha$-amorphene & 0.61 & 0.16 & 1481 & $a, b, c$ \\
\hline 26 & Zingiberene & 1.24 & 0.45 & 1482 & $a, b, c$ \\
\hline 27 & Viridiflorene & - & 1.83 & 1484 & $a, b, c$ \\
\hline 28 & Bicyclogermacrene & 3.68 & 3.55 & 1486 & $a, b, c$ \\
\hline 29 & $\alpha$-muurolene & 0.84 & 0.48 & 1487 & $a, b, c$ \\
\hline 30 & Trans- $\alpha$-farnesene & 0.51 & 0.33 & 1489 & $a, b, c$ \\
\hline 31 & Cis- $\alpha$-bisabolene & 1.15 & 0.67 & 1492 & $a, b, c$ \\
\hline 32 & $\gamma$-cadinene & 1.29 & 2.07 & 1494 & $a, b, c$ \\
\hline 33 & $\delta$-cadinene & 4.60 & 2.61 & 1495 & $a, b, c$ \\
\hline 34 & Trans-cadina-1,4-diene & 0.84 & 1.41 & 1496 & $a, b, c$ \\
\hline 35 & Elemol & 0.23 & - & 1501 & $a, b, c$ \\
\hline 36 & Palustrol & - & 0.18 & 1530 & $a, b, c$ \\
\hline 37 & 1,6-germacradien-5-ol & 2.93 & - & & $a, b, c$ \\
\hline 38 & Caryophyllene oxide & 1.32 & 4.50 & 1538 & $a, b, c$ \\
\hline 39 & Globulol & - & 1.08 & 1545 & $a, b, c$ \\
\hline 40 & Viridiflorol & 0.25 & 0.26 & 1553 & $a, b, c$ \\
\hline 41 & Ledol & 0.54 & 0.53 & 1563 & $a, b, c$ \\
\hline 42 & 6-oplopenone & 0.21 & 0.32 & 1573 & $a, b, c$ \\
\hline 43 & $\alpha$-muurolol & 3.69 & 1.73 & 1595 & $a, b, c$ \\
\hline 44 & T-cadinol & 1.60 & 2.05 & 1596 & $a, b, c$ \\
\hline 45 & T-muurolol & 3.43 & 3.90 & 1609 & $a, b, c$ \\
\hline 46 & $\alpha$-cadinol & 12.21 & 13.69 & 1622 & $a, b, c$ \\
\hline 47 & 14-hidroxy-9-epi-cayophyllene & 8.56 & 15.38 & 1645 & $a, b, c$ \\
\hline 48 & Abietadiene & 7.29 & 7.45 & 2012 & $a, b, c$ \\
\hline 49 & n.i & - & 0.29 & 2016 & $a, b, c$ \\
\hline 50 & Calyculone & 0.28 & 0.22 & 2016 & $a, b, c$ \\
\hline 51 & $\begin{array}{l}\text { S-Indacene-1,7-dione, 2,3,5,6-tetrahydro-3,3,4,5,5,8- } \\
\text { hexamethyl- }\end{array}$ & - & 0.51 & 2075 & $a, b, c$ \\
\hline 52 & Manoyl oxide & 1.43 & 2.90 & 2089 & $a, b, c$ \\
\hline 53 & Cembrene & - & 0.16 & 2097 & $a, b, c$ \\
\hline 54 & $9 \beta, 13 \beta$-epoxy-7-abietene & 0.31 & 0.45 & 2097 & $d^{*}$ \\
\hline 55 & n.i & - & 0.20 & 2136 & $a, b, c$ \\
\hline 56 & 13- $\alpha, 15$ - $\alpha$-epoxyabiet-8-ene & - & 0.16 & 2161 & $a, b, c$ \\
\hline 57 & (1E,3Z,11E)-Cembra-1,3,11-trien-6-one & - & 0.60 & 2173 & $a, b, c$ \\
\hline 58 & 6-7-dehidroroyleanone & 5.80 & 9.61 & 2192 & $d^{*}$ \\
\hline 59 & Anthracene, 1,4-dimethoxy-9-phenyl & - & 0.99 & 2244 & $a, b, c$ \\
\hline 60 & n.i & - & 0.15 & 2256 & $a, b, c$ \\
\hline \multirow[t]{10}{*}{61} & Gibberellin A3 & - & 0.28 & 2225 & $a, b, c$ \\
\hline & Total identified & 99.74 & 99.38 & & \\
\hline & Hydrocarbon Monoterpenes & 6.78 & 1.72 & & \\
\hline & Oxygenated Monoterpenes & 16.44 & 9.08 & & \\
\hline & Hydrocarbon Sesquiterpenes & 26.44 & 21.63 & & \\
\hline & Oxygenated Sesquiterpenes & 34.97 & 43.62 & & \\
\hline & Diterpene hydrocarbons & 7.29 & 7.45 & & \\
\hline & Oxygenated diterpenes & 7.82 & 15.60 & & \\
\hline & Not identified (n.i) & - & 0.64 & & \\
\hline & Other Compounds & - & 0.28 & & \\
\hline
\end{tabular}

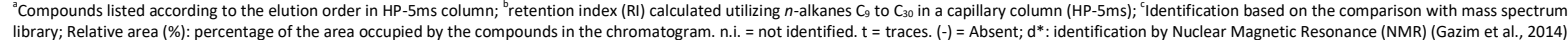




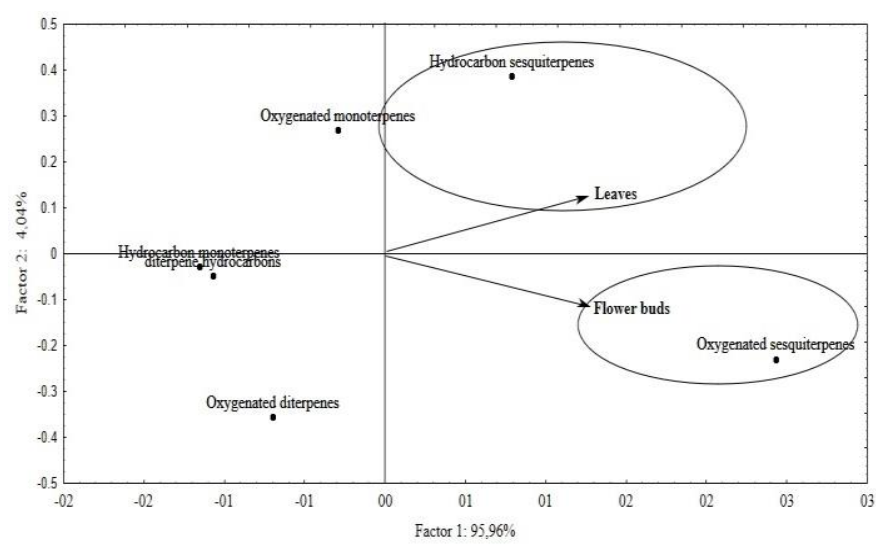

Fig 1. Biplot of PCA scores and loadings for the GC-MS representing the projection of chemical classes of the essential oil from Tetradenia riparia (Hochst.) (Lamiaceae) leaves and flowers buds.

Table 2. Larval mortality (\%) of essential oil from Tetradenia riparia leaves and flower buds on Rhipicephalus sanguineus larvae.

\begin{tabular}{lcc}
$\begin{array}{l}\text { Concentration } \\
(\mathrm{mg} / \mathrm{mL})\end{array}$ & $\begin{array}{c}\text { Essential Oil } \\
\text { from leaves }\end{array}$ & $\begin{array}{c}\text { Essential Oil } \\
\text { from flower buds }\end{array}$ \\
\hline Positive control & $100^{\mathrm{A}, \mathrm{a}}$ & $100^{\mathrm{A}, \mathrm{a}}$ \\
25.00 & $100^{\mathrm{A}, \mathrm{a}}$ & $100^{\mathrm{A}, \mathrm{a}}$ \\
12.50 & $100^{\mathrm{A}, \mathrm{a}}$ & $90.64 \pm 2.71^{\mathrm{B}, \mathrm{b}}$ \\
6.25 & $90.61 \pm 1.21^{\mathrm{AB}, \mathrm{a}}$ & $70.48 \pm 2.24^{\mathrm{BC}, \mathrm{b}}$ \\
3.12 & $80.77 \pm 0.72^{\mathrm{BC}, \mathrm{a}}$ & $65.85 \pm 6.47^{\mathrm{C}, \mathrm{b}}$ \\
1.50 & $69.59 \pm 6.38^{\mathrm{C}, \mathrm{a}}$ & $36.68 \pm 4.18^{\mathrm{C}, \mathrm{b}}$ \\
0.70 & $30.46 \pm 1.92^{\mathrm{D}, \mathrm{a}}$ & $18.88 \pm 1.92^{\mathrm{D}, \mathrm{b}}$ \\
0.39 & $0.00^{\mathrm{E}, \mathrm{c}}$ & $0.00^{\mathrm{E}, \mathrm{c}}$ \\
Negative control & $0.00^{\mathrm{E}, \mathrm{c}}$ & $0.00^{\mathrm{E}, \mathrm{c}}$
\end{tabular}

Values presented with average \pm standard deviation. Different capital letters in the same column and small letters in the same row indicate significant difference by Tukey's test ( $p \leq 0.05)$. Positive control: commercial organophosphorus (cypermethrin $15 \%$; chlorpyrifos $25 \%$; citronellal $1 \%$ ). Negative control: polysorbate 80 aqueous solution $2 \%$.

Table 3. Lethal concentrations $\left(\mathrm{LC}_{50}\right.$ and $\left.\mathrm{LC}_{99.9} \mathrm{mg} / \mathrm{mL}\right)$ of essential oil from Tetradenia riparia leaves and flower buds on Rhipicephalus sanguineus larvae by Probit analysis.

\begin{tabular}{lll}
\hline & $\mathbf{C L}_{50}$ & $\mathbf{L C}_{99.9}$ \\
\hline Positive Control & $0.019 \pm 0.001^{\mathrm{a}}$ & $0.20 \pm 0.015^{\mathrm{a}}$ \\
& $\left({ }^{*}\right)$ & $\left({ }^{*}\right)$ \\
Essential oil & $2.18 \pm 0.24^{\mathrm{b}}$ & $9.98 \pm 0.10^{\mathrm{b}}$ \\
From leaves & $(1.73-2.63)$ & $(9.49-10.46)$ \\
& & \\
Essential oil & $5.36 \pm 0.50^{\mathrm{c}}$ & $20.26 \pm 0.59^{\mathrm{c}}$ \\
from flower buds & $(2.51-8.21)$ & $(19.77-20.75)$ \\
& &
\end{tabular}

Values presented with average \pm standard deviation. Different letters in the same column indicate significant difference by Tukey's test $(p \leq 0.05)$. $\mathrm{LC}_{50}$ : lethal concentration $50 \%$; $\mathrm{LC}_{99.9}$ : lethal concentration 99.9\%; Cl: confidence interval. Positive control: commercial organophosphorus. 


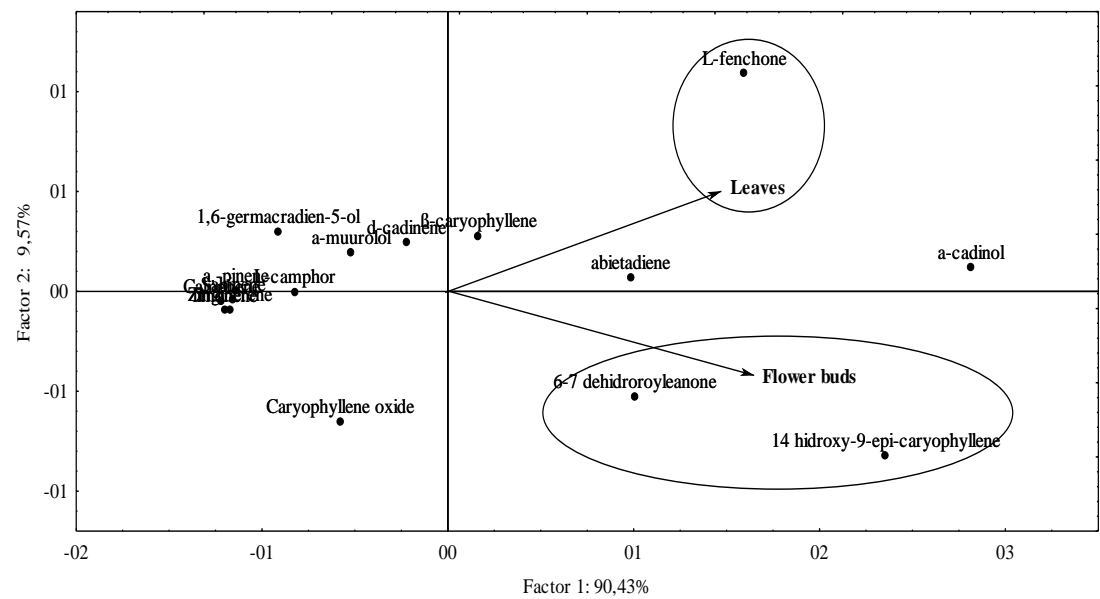

Fig 2. Biplot of PCA scores and loadings for the GC-MS representing the projection of chemical compounds of the essential oil from Tetradenia riparia (Hochst.) (Lamiaceae) leaves and flowers buds.

Table 5. Bioinseticidal activities of monoterpenes found in essential oil from Tetradenia riparia leaves and flower buds.

\begin{tabular}{|c|c|c|}
\hline Monoterpenes & Chemical structure & bioinseticidal activities \\
\hline Limonene & & $\begin{array}{l}\text { Insecticide (Nakatani 1999, Prates \& Santos 2000, Trumble 2002, Júnior 2003, Lee et al. 2003, } \\
\text { Moreira et al. 2006, Tripathi et al. 2016, Niculau et al. 2013). } \\
\text { Larvicide (Santos et al. 2011). } \\
\text { Acaricide (Jaenson et al. 2005, Badawy et al. 2010, Roh et al. 2013, Abdelgaleil et al. 2019). }\end{array}$ \\
\hline Fenchona & & $\begin{array}{l}\text { Acaricide (Sánchez-Ramos \& Castañaera 2001, Lee 2004, Lage et al. 2015, Abdelgaleil et al. } \\
\text { 2019). } \\
\text { Insecticide (Kim \&Ahn 2001). }\end{array}$ \\
\hline$\alpha$-pinene & & Insecticide (Harborne \& Baxter 1993, Júnior 2003). \\
\hline 8-pinene & & $\begin{array}{l}\text { Insecticide (Nakatani et al. 1998, Júnior 2003). } \\
\text { Larvicide (Pohilt et al. 2011). }\end{array}$ \\
\hline L-camphor & & Repellent (Negahban et al. 2007; Jeon et al. 2014) \\
\hline B-caryophyllene & & Larvicide (Santos et al. 2012). \\
\hline
\end{tabular}

Table 4. Inhibiting activity of acetylcholinesterase enzyme at different concentrations of essential oil (EO) from Tetradenia riparia leaves and flower buds by bioautographic method.

\begin{tabular}{llll} 
Inhibition of acetylcholinesterase enzyme & & \\
\hline Concentration $(\mathrm{mg} / \mathrm{mL})$ & $\begin{array}{l}\text { EO from Tetradenia riparia } \\
\text { leaves }\end{array}$ & $\begin{array}{l}\text { EO from Tetradenia riparia } \\
\text { flower buds }\end{array}$ & $\mathrm{CP}$ \\
\hline 45.00 & +++ & ++ & +++ \\
22.50 & ++ & ++ & +++ \\
11.25 & ++ & + & +++ \\
5.62 & ++ & + & ++ \\
2.81 & + & + & ++ \\
1.40 & + & + & + \\
0.70 & + & - & +
\end{tabular}

PC: Positive control: commercial organophosphorus (cypermethrin 15\%; chlorpyrifos $25 \%$; citronellal $1 \%) ;(+++)$ : strong inhibition of acetylcholinesterase enzyme; (++): moderate inhibition; $(+)$ : weak inhibition; (-): absence of inhibition. EO: essential oil. 
cause mortality to $100 \%$ of $R$. (B.). microplus larvae while it took (+)-isopinocamphor 45 minutes of contact. According to Wright (1975), the action mechanism of camphor is already known, blocking the olfactory receptors of insects. Another monoterpene found in T. riparia $\mathrm{EO}_{\mathrm{L}}$ and $\mathrm{EO}_{\mathrm{FB}}$ is 6 caryophyllene; this compound is also found in Alpinia purpurata essential oil and showed activity against $A$. aegypti larvae ( $\mathrm{LC}_{50} 0.071 \mathrm{mg} / \mathrm{mL}$ ) (Santos et al., 2012). Therefore, the results found in our experiment, along the data found in the literature, suggest that monoterpenes may have been responsible for the larvicidal activity which was found.

Another aspect refers to recent research studies with other plant species in order to propose new biomolecules with biocide potential against $R$. sanguineus. In this context, Goode, Ellse and Wall (2018) utilized Curcuma longa (Zingiberaceae) essential oil at the concentration of 25 $\mathrm{mg} / \mathrm{mL}$, observing some $R$. sanguineus detachment from the animal body. Godara et al. (2013) evaluated chloroform extract of Absinthe (Artemisia absinthium) (Asteraceae) aerial parts at the concentration of $200 \mathrm{mg} / \mathrm{mL}$ indicating a mortality rate of $93.3 \%$ for adult tick and also reducing the hatching of $R$. sanguineus eggs at the concentrations of 50, 100 and $200 \mathrm{mg} / \mathrm{mL}$. Perpetua et al. (2009) tested Neem (Azadirachta indica) (Meliaceae) oil at the concentration of $100 \mathrm{mg} / \mathrm{mL}$ at the dose of $0.6 \mathrm{~mL} / \mathrm{kg}$ under top spot applications every 5 days for a 30-day period, showing to be efficient to control $R$. sanguineus tick. Studies developed by Silva et al. (2007) evaluated the effect of Neem (Azadirachta indica) and lemongrass (Cymbopogon citratus) (Poaceae) alcoholic extract against $R$. sanguineus engorged females and found a decrease of reproductive efficiency (27.6\%) for Azadirachta indica and $28.6 \%$ for Cymbopogon citratus. The efficiency of Neem was also evaluated in a field test by Weeb and David (2002), because engorged females submitted to the action of this substance presented partial lay with $0 \%$ hatchability and $100 \%$ efficiency.

Our experiment also evaluated the probable action mechanism of EOs, measuring the inhibitory power of acetylcholinesterase enzyme. The results (Table 4) indicated that the EO from leaves inhibited the enzyme up to 0.70 $\mathrm{mg} / \mathrm{mL}$ and the EO from flower buds up to $1.40 \mathrm{mg} / \mathrm{mL}$. The in vitro bioautographic results were superior to the LCs on in vivo larvae (Table 4), justified by the absence of physiological conditions that interfere in the biochemical reactions of mite because the bioautographic protocol is carried out in controlled environment with all pre-established conditions, without interference of the cellular wall permeability, molecule size and solubility of these molecules in hydrophilic and lipophilic media (Brain et al., 2007).

The importance to establish the action mechanism of $T$. riparia EOs is related to the action mechanism of chemical acaricides and larvicides utilized in the control of fleas and ticks in dogs that act by inhibiting the receptor of the neurotransmitter gamma-aminobutyric acid (GABA) and glutamate receptor that act on the neuromuscular joint of insects. Therefore, because it presents the inhibitory effect of acetylcholinesterase (Ache), T. riparia EO becomes an alternative for the resistance these chemical acaricides may present since the excessive utilization, without understanding the ecology and epidemiology of ticks with the detection flaws, caused resistance development to almost all drug classes (Pereira et al., 2008).

\section{Materials and methods}

\section{Plant material}

Tetradenia riparia flower buds and leaves were manually collected at the Medicinal Garden of the Paranaense University (UNIPAR) (23 46.225'S 53⒗730'W, 391m), state of Paraná - Brazil, in the beginning of the morning from 8:00 to 10:00 am. The collection time happened with the emergence of flower buds that occurred in the winter (June 21, 2017 to July 13, 2017). A sample was authenticated and deposited in the educational herbarium of the Paranaense University (HEUP), under the number 2502. This species is recorded in the National System of Genetic Patrimony Management and Associated Traditional Knowledge (SisGen) under the registration number AA6C8A8.

\section{Essential oil extraction}

The extraction of $T$. riparia essential oil was by hydro distillation (3 hours) (Gazim et al., 2014). The essential oil was withdrawn with $n$-hexane, filtered with anhydrous sodium sulfate $\left(\mathrm{Na}_{2} \mathrm{SO}_{4}\right)$, stored in flasks and kept under refrigeration at $-4 \stackrel{\circ}{\circ}$ until total evaporation of $n$-hexane. The essential oil yield was determined through the ratio of dry leaves mass and fresh flower bud ( $\mathrm{g}$ ) by essential oil mass (g) (\%).

\section{Essential oil chemical characterization}

The essential oil chemical identification was carried out by GC-MS using a Gas Chromatographer, Agilent 7890B, coupled to a Mass Spectrometer, Agilent 5977 A MSD, and a HP5-MS UI - Agilent fused silica capillary $(30 \times 250 \mu \mathrm{m} \times 0.25 \mu \mathrm{m}$; Agilent Technologies), with initial oven temperature from $80{ }^{\circ} \mathrm{C}$ ( $\left.1 \mathrm{~min}\right)$, followed by increased to $185^{\circ} \mathrm{C}$ at $2{ }^{\circ} \mathrm{C} / \mathrm{min}$ and maintained for $1 \mathrm{~min}$, followed by an increase to $275^{\circ} \mathrm{C}$ at $9{ }^{\circ} \mathrm{C} / \mathrm{min}$ and maintained for $2 \mathrm{~min}$ and finally increase to $300^{\circ} \mathrm{C}$ at $25^{\circ} \mathrm{C} / \mathrm{min}$ and maintained for 1 min. Helium was utilized as the carrier gas at the linear speed of $1 \mathrm{~mL} / \mathrm{min}$ up to $300{ }^{\circ} \mathrm{C}$, and pressure release of 56 $\mathrm{kPa}$. The injector temperature was $280^{\circ} \mathrm{C}$; the injection volume was $1 \mu \mathrm{L}$; the injection occurred in split mode (2:1).The temperatures of the transfer line, ion source and quadrupole were 280,230 and $150^{\circ} \mathrm{C}$, respectively. The EM detection system was utilized in "scan" mode, at the mass/charge rate/load $(\mathrm{m} / \mathrm{z})$ of $40-600$, with "solvent delay" of $3 \mathrm{~min}$. The compounds were identified by comparing the mass spectra found in NIST 11.0 libraries and by comparing the retention indices (RI) obtained by a homologous series of $n$-alkane standard (C7-C28) (Adams, 2017).

\section{Principal component analysis (PCA)}

A multivariate analysis was also done to determine the principal component analysis (PCA) which allowed the evaluation of the major chemical compounds and chemical class of all compounds found in the essential oil from leaves and floral bud. The analysis result was graphically presented (biplot), helping the characterization of the analyzed variable groups (Moita Neto and Moita, 1998).

For each sample of the essential oil from leaves and floral buds, the identified major chemical compounds and their respective chemical classes (Table 1 ) were plotted. Data 
were transformed in orthogonal latent variables called principal components which are linear combinations of original variables created with the eigenvalues of the data covariance matrix (Hair et al., 2005). Kaiser's criterion was utilized to choose the principal components and an eigenvalue preserved the relevant information when it was greater than the unit. This analysis was carried out in two ways: the former contained only data referring to the chemical composition of major compounds obtained in three periods, and the latter analyzed the grouped chemical classes to which those compounds belong to (Ferré, 1995; Camacho et al., 2010). Both analyses were done utilizing Statistica 7 software. (Statsoft Inc, 2018).

\section{Essential oil larvicidal activity}

The larval sensitivity was determined by Larval Packet Test, described by Leite et al. (1995) and Fernandes et al. (2008) where approximately 100 larvae were placed on $2 \times 2 \mathrm{~cm}$ filter paper recently impregnated with dilutions of $T$. riparia EO forming a "sandwich", sealed and stored in a Petri dish. The EO dilutions ranged from 500 to $0.47 \mathrm{mg} \mathrm{mL}^{-1}$. For this bioassay, two control groups were made: a positive control utilizing a conventional acaricide with (cypermethrin 15\%; chlorpyrifos $25 \%$; citronellal $1 \%$ ) at the concentration of $0.005 \%$, and a negative control using an aqueous solution of polysorbate $(80)$ at $2.0 \%$. The envelopes were stored at ambient temperature and the readings were done after 24 $h$, separating live larvae from the dead ones, utilizing an entomological loupe. The assays were carried out in triplicate for each EO dilution used in larvae. The calculation of larval mortality was done through Equation I.

\section{Mortality $(\%)=$ dead larvae $\times 100 /$ total larvae (Equation I)}

\section{Essential oil anticholinesterase activity}

The anticholinesterase activity was determined by bioautographic method described by Marston et al., (2002), with modifications (Yang et al., 2009). T. riparia EOs were tested from a concentration ranging from 45.00 to 0.70 $\mathrm{mg} / \mathrm{mL}$, diluted in methanol. The samples were plotted in aluminum chromatoplates $(10 \times 10 \mathrm{~cm}$, silica gel $60 \mathrm{~F} 254$ with $0.2 \mathrm{~mm}$ of thickness), after plotting the plates were dried and a solution of acetylcholinesterase enzyme buffer solution was sprayed on them; next, a solution of $\alpha$-naftyl acetate was sprayed. The plates were kept at $37^{\circ} \mathrm{C}$ during 20 minutes. After this period, the chromatoplates were sprayed with Fast Blue B salt reagent, resulting in a purple color surface. The larvicide (cypermethrin 15\%; chlorpyrifos $25 \%$; citronellal $1 \%$ ) was used as negative control.

The tests were done in triplicate and the results were expressed as averages and their corresponding standard deviation. The data were processed and submitted to analysis of variance (ANOVA), and the differences between the averages were determined by Tukey's test or ScottKnott's test at $5 \%$ significance level.

\section{Statistical analysis}

The experimental design was completely randomized. The data were processed and submitted to analysis of variance (ANOVA) and the differences between the arithmetical averages and the standard deviation were determined by
Tukey's test at $5 \%$ of significance. The lethal concentrations that killed $50 \%\left(\mathrm{LC}_{50}\right)$ and $99.9 \%$ ( $\left.\mathrm{LC}_{99}\right)$ of tick larvae and the respective $\mathrm{Cl}(5 \%)$ were calculated by Probit analysis (ED 50 Plus 1.0). All the tests were carried out in triplicate.

\section{Conclusion}

The essential oil extracted from Tetradenia riparia leaves and flower buds were tested against Rhipicephalus sanguineus larvae. The presence of monoterpenes: limonene, L-fenchone, $\alpha$ and 6 -pinene and L-camphor in greater amount in leaves provided greater potential against Rhipicephalus sanguineus larvae ( $\mathrm{LC}_{99.9}: 9.98 \pm 0.10 \mathrm{mg} / \mathrm{mL}$ ) when compared to the essential oil extracted from flower buds ( $L C_{99.9}: 20.12 \pm 0.54 \mathrm{mg} / \mathrm{mL}$ ). The action mechanism through which the oil killed larvae was by inhibition of the acetylcholinesterase enzyme at the concentration of 0.70 $\mathrm{mg} / \mathrm{mL}$ (leaves) and $1.40 \mathrm{mg} / \mathrm{mL}$ (flower buds), indicating the presence of molecules in the essential oil from $T$. riparia leaves with biocide potential.

\section{Acknowledgment}

The authors thank Universidade Paranaense- UNIPAR, Centro Universitário de Maringá- UNI-Cesumar Coordenação de Aperfeiçoamento de Pessoal de Nível Superior - Brazil (CAPES), Conselho Nacional de Desenvolvimento Científico e Tecnológico (CNPq) for the fellowship and financial support.

\section{Conflict of interest}

The authors have no conflicts of interest to declare

\section{References}

Abdelgaleil SA, Badawy ME, Mahmoud NF, Marei AESM (019). Acaricidal activity, biochemical effects and molecular docking of some monoterpenes against twospotted spider mite (Tetranychus urticae Koch). Pest Biochem Physiol. 156: 105-115.

Adams RP (2017) Identification of essential oil componentes by Gas Chomatography/Mass Spectrometry, 4th ed. Allured Publishing Corporation. 804p.

Badawy MEI, Abdelgaleil SAM (2010). Acaricidal and quantitative structure activity relationship of monoterpenes against the two-spotted spider mite, Tetranychus urticae. Exp Appl Acarol. 52:261-274.

Badawy MEI, Abdelgaleil SAM (2010). Acaricidal and quantitative structure activity relationship of monoterpenes against the two-spotted spider mite, Tetranychus urticae. Exp Appl Acarol. 52:261-274.

Boily Y, Van Puyvelde L (1986) Screening of medicinal plants of Rwanda (Central Africa) for antimicrobial activity. J Ethnopharmacol. 16: 1-13

Borges LMF, Soares SF, Fonseca IN, Chaves VV, Louly CCB (2007). Resistência acaricida em larvas de Rhipicephalus sanguineus (Acari: Ixodidae) de Goiânia-GO, Brasil. Rev Patol Trop. 36 (1): 87-95.

Bortolucci WC, Oliveira HLM, Silva ES, Boas MRV, Carvalho TM, Campos CFA, Gonçalves JE, Júnior RP, Gazim ZC (2018) Acaricidal and larvicidal activity of leaves and fractions of rose pepper (Schinus terebinthifolius Raddi. (Anacardiaceae) essential oil against Rhipicephalus (Boophilus) microplus. Aust J Crop Sci. 12(10):1645-1652.

Brain KR, Green DM, Api, AM (2007) In vitro human skin penetration of the fragrance material geranyl nitrile. Toxicol in vitro. 21: 133-138.

Brito LG, Barbieri FS, Rocha RB, Oliveira MCS, Ribeiro ES (2011). Evaluation of the Efficacy of Acaricides Used to Control the Cattle Tick, Rhipicephalus microplus, in Dairy Herds Raised in the Brazilian Southwestern Amazon. Vet Med Int. 1-6.

Camacho J, Picó J, Ferrer A (2010) Data understanding with PCA: structural and variance information plots. Chemometr. Intell. Lab. Syst. 100(1): 48-56.

Campbell WE, Gammon DW, Smith P, Abrahams M, Purves TD (1997). Composition and antimalarial activity in vitro of the essential oil of Tetradenia riparia. Planta Médica. 63(1): 270-272.

Cardoso BM, Mello TFP, Lopes SN, Demarchi IG, Lera DSL, Pedroso RB, Cortez DA, Gazim ZC, Aristides SMA, Silveira TGV, Lonardoni MVL (2015) Antileishmanial activity of the essential oil from Tetradenia riparia obtained in different seasons. Mem Inst Oswaldo Cruz. 110(8): 1024-1034.

Cunha NC, Fonseca AH, Rezende J, Rozental T, Favacho ARM, Barreira JD, Massard CL, Lemos ERS (2009). First identification of natural infection of Rickettsia rickettsii in the Rhipicephalus sanguineus tick, in the State of Rio de Janeiro. Pesq Vet Bras 29(2):105108.

Demarchi IG, Terron Md-S, Thomazella MV, Pedroso RB, Gazim ZC, Cortez DAG Aristides SMA (2015) Immunomodulatory activity of essential oil from Tetrania riparia (Hochstetter) Codd in murine macrophages. Flavour Fragr J. 30(6): 428-438. 
Fernandes FF, Freitas EPS (2001) Analysis of the use of fenthion via epicutaneous in dogs for Rhipicephalus sanquineus control. Rev Soc Bras Med Trop. 34: 339-342.

Ferré $L$ (1995) Selection of components in principal component analysis: a comparison of methods. Comput Stat. Data Anal. 19: 669-682.

Garcia ES, Azambuja P (2004) Lignoids in insects: chemical probes for the study of ecdysis, excretion and Trypanosoma cruzi-triatomine interactions. Toxicon. 44: 431-440.

Gazim ZC, Amorim ACL, Hovell AMC, Rezende AM, Nascimento IA, Ferreira GA, Cortez DAG (2010) Seasonal variation, chemical composition, and analgesic and antimicrobial activities of the essential oil from leaves of Tetradenia riparia (Hochst.) Cdd in suthern Brazil. Molecules. 15(8): 5509-5524.

Gazim ZC, Demarchi IG, Lonardoni MVC, Amorim ACL, Hovell AMC, Rezende CM, Ferreira GA, De Lima EL, De Cosmo FA, Cortez DAG (2011) Acaricidal activity of the essential oil from Tetradenia riparia (Lamiaceae) on the cattle tick Rhipicephalus (Boophilus) microplus (Acari; Ixodidae). Exp Parasitol. 129: 175-178

Gazim ZC, Rodrigues F, Amorin A, Rezende C, Sokovi M, Te?evi V, Vcč, Krsti' G, Cortez L, Colauto N, Linde G, Cortez D (2014) New Natural Diterpene-Type Abietane from Tetradenia riparia Essential Oil with Cytotoxic and Antioxidant Activities. Molecules (Basel. Online). 19: 514-524.

Godara S, Parveen S, Katoch R, Yadav A, Verma PK, Katoch M, Kaur D, Ganai A, Raghuvanshi P, Singh NK (2013) Acaricidal activity of extract of Artemisia absinthium against Rhipicephalus sanguineus of dogs. Parasitol Res. 113(2): 747-754.

Goode P, Ellse L, Wall R (2018) Preventing tick attachment to dogs using essential oils. Ticks and Tick-borne Diseases. 1-6. In press.

Hair JF, Anderson RE, Tatham RL, Black W, Hair J (2005) Análise Multivariada de Dados, 3th ed. Bookman, Porto Alegre.

Jeyathilakan N, Sundar STB, Sangaran A, Latha BR (2019) In vitro Acaricidal Effect of Aqueous Leaf Extract of Nicotiana tabacum on Brown Dog Tick, Rhipicephalus sanguineus. Indian Vet. J. 96(4): 17-18.

Kostyukovsky M, Ravid U, Shaaya E (2002) The potential use of plant volatiles for the control

of stored product insects and quarantine pests in cut flowers. Acta Hort. 576: 347-358.

Lee HS (2004) Acaricidal activity of constituents identified in Foeniculum vulgare fruit oil against Dermatophagoides spp.(Acari: Pyroglyphidae). J Agric Food Chem. 52(10): 2887-2889.

Leite RC, Labruna MB, Oliveira PR (1995) In vitro susceptibility of engorged females from different populations of Boophilus microplus to commercial acaricides. Rev Bras Parasitol Vet. 4(2): 283-294.

Magalhães CRI, Oliveira CRF, Matos CHC, Brito SSS, Magalhães TA, Ferraz MSS (2015) Potencial inseticida de óleos essenciais sobre Tribolium castaneum em milho armazenado. Rev Bras PI Med. 17(4): 1150-1158.

Marston A, Kissling J, Hostettmann KA (2002). A rapid TLC bioautography method for the detection of acetylcholinesterase and butyrylcholinesterase inhibitors in plants. Phytochem. 13: 51-54.

Martins MBG, Martins RG, Cavalheiro JA (2008) Histoquímica e atividade antibacteriana de folhas do incenso (Tetradenia riparia). Rev Biociências. 14(1): 127-140.

Melo NI, Carvalho CE, Fracarolli L, Cunha WR, Veneziani RCS, Martins CHG, Crotti AEM (2015) Antimicrobial activity of the essential oil of Tetradenia riparia (Hochst.) Codd. (Lamiaceae) against cariogenic bacteria. Braz J Microbiol. 46: 519-525.

Moita Neto JM, Moita GC (1998) Na introduction analysis exploratory multivariate date. Quím Nova. 21: 467-469.

Moreira MD, Picanço MC, Silva EM, Moreno SC, Martins JC (2006) Uso de inseticidas botânicos no controle de pragas. Controle alternativo de pragas e doenças. Viçosa: Epamig/CTZM. 1: 89-120.

Ndamane Y, Kambizi L, Songca SP, Oluwafemi OS (2013) Antibacterial effectiveness of Tetradenia riparia extract, a plant traditionally used in the Eastern Cape Province to treat diseases of the respiratory system. J Med Plants Res. 7(1): 2755-2760.

Njau EFA, Alcorn JM, Buza J, Chirino-Trejo M, Ndakidemi P (2014) Antimicrobial activity of Tetradenia riparia (Hochst.) Lamiaceae, a medicinal plant from Tanzania. Eur J Med Plants. 4: 1462-1478.

Okem A, Finnie JF, Van Staden J (2012) Pharmacological, genotoxic and phytochemical properties of selected South African medicinal plants used in treating stomach-related ailments. J. Ethnopharmacol. 139: 712-720.

Omolo MO, Okinyo D, Ndiege IO, Lwande W, Hassanali A (2004) Repellency of essential oils of some Kenyan plants against Anopheles gambiae. Phytochemistry. 65: 27972802
Paz GF, Leite RC, Oliveira P (2008) Control of Rhipicephalus sanguineus (Latreille, 1806) (Acari: Ixodidae) in the kennel of the UFMG Veterinary School. J Vet Parasitol. 17(1): 41-44.

Pereira MC, Labruna MB, Szabó MP, Klafke GM (2008) Rhipicephalus (Boophilus) microplus. Biologia, Controle e Resistência. Ed Med Vet. São Paulo. Brasil. 169 pp.

Perpétua PCG, Liberati MN, Simonelli SM, Leonardo JMLO (2009) Eficácia do óleo de nim (Azadirachta indica) no controle do carrapato do cão (Rhipicephalus sanguineus). Encontro Internacional de Produção Científica Cesumar, Maringá, PR, p. 1-5. (Resumo).

Prates HT, Oliveira AB, Leite RC, Craveiro AA (1993) Atividade carrapaticida e composição química do óleo essencial do capim-gordura. Pesq Agropec Bras. 28: 621-625.

Prates HT, Leite RC, Craveiro AA, Oliveira AB (1998) Identification of some chemical components of the essential oil from molasses grass (Melinis minutiflora Beauv.) and their activity against cattle-tick (Boophilus microplus). J Braz Chem. Soc. 9: 193-197.

Raimundo KF, Bortolucci WC, Silva ES, Pereira AFB, Sakai OA, Júnior RP, Gonçalves JE, Linde GA, Gazim ZC (2017) Chemical composition of garlic wood (Gallesia integrifolia) (Phytolaccaceae) volatile compounds and their activity on cattle tick. Aust J Crop Sci. 11(08):1058-1067.

Salkeld DJ, Porter WT, Loh SM, Nieto NC (2019) Time of year and outdoor recreation affect human exposure to ticks in California, United States. Ticks and Tick-Borne Diseases. In press.

Sánchez-Ramos I, Castañera P (2001) Acaricidal activity of natural monoterpenes on Tyrophagus putrescentiae (Schrank), a mite of stored food. J Stored Prod Res. 37(1): 93-101.

Santos GKN, Dutra KA, Barros RA, da Camara CAG, Lira DD, Gusmao NB, Navarro DMAF (2012) Essential oils from Alpinia purpurata (Zingiberaceae): chemical composition, oviposition deterrence, larvicidal and antibacterial activity. Ind Crop Prod. 40:254-260.

Silva WW, Athayde ACR, Rodrigues OG, Araújo GMB, Santos VD, Neto ABS, Coelho MCOC, Marinho ML (2007) Efeitos do Neem (Azadirachta indica A. juss) e do Capim Santo (Cymbopo goncitratus (DC) Stapf) sobre os parâmetros reprodutivos de fêmeas ingurgitadas de Boophilus micropluse Rhipicephalus sanguineaus (Acari: Ixodidae) no semi-árido paraibano. Rev Bras Plantas Med. 9(3): 1-5.

Souza VC, Lorenzi H (2005) Botânica Sistemática. Guia ilustrado para identificação das famílias de Angiospermas da flora brasileira, baseado em APG II. Nova Odessa, SP. Instituto Plantarum.

Statsoft Inc (2018) Statistica for Windows (Computer Program Manual). (Accessed July 17 2001). http://www.statsoft.com/.

Sugauara EYY, Sugauara EY, Sugauara RR, Bortolucci WC, Oliveira HLM, Silva ES, Campos CFAA, Gonçalves JE, Colauto NB, Gazim ZC, Linde GA (2019) Control of bovine tick [Rhipicephalus (Boophilus) microplus] with Brunfelsia uniflora leaf extract. Aust J Crop Sci. 13(06):903-910.

Sutherst RW, Jones RJ, Schnitzerling HJ (1982) Tropical legumes of the genus Stylosanthe immobilize and kill cattle ticks. Nature. 295: 320-321.

Szabó MPJ, Garcia CA, Silva TL, Olegário MMM, Campos VA, Castro IP (2009) Efeito acaricida da mistura oxigênio-ozônio sobre o carrapato Rhipicephalus sanguineus. Vet Not. 15(2)

Tripathi AK, Mishra S (2016) Plant monoterpenoids (Prospective Pesticides). Ecofriendly Pest Management for Food Security. 16: 507-524.

Van Puyvelde L, De Kimpe N (1986) Active principles of Tetradenia riparia. I. Antimicrobial activity of 8(14),15- sandaracopimaradiene-7a,18-diol. J Ethnopharm. 17:269-275.

Van Puyvelde L, Ntawukiliyayo JD, Portaels F, Hakizamungu E (1994) In vitro inhibition of mycobacteria by Rwandese medicinal plants. Phytother Res. 8(2): 65-9.

Webb EC, David M (2002) The efficacy of neem seed extract (Azadirachta indica) to control tick infestation in Tswana, Simmentaler and Brahman cattle. S Afr J Anim Sci. 32(1): 1-6.

Wright RH (1975) Why mosquito repellents repel. Sci Am. 233: 104-111.

Xavier FG, Righi DA, De Souza Spinosaii H (2007). Toxicologia do praguicida aldicarb ("chumbinho"): aspectos gerais, clínicos e terapêuticos em cães e gatos. Cienc Rural. 37(4): 1206-1211.

Yang ZD, Zhang X, Duan DZ, Song Z, Yang MJ, Li S (2009) Modifiel TLC bioautographie method for screening acetylcholinesterase inhibitors from plant extracts. J Sep Sci. 32 3257-3259.

York T, Van Vuuren SF, De Wet $H$ (2012) An antimicrobial evaluation of plants used for the treatment of respiratory infections in rural Maputaland, KwaZulu-Natal, South Africa. J Ethnopharmacol. 144: 118-12. 